\title{
Analisis Kinerja Jaringan Hybrid Kooperatif Device-to-Device 5G menggunakan Teknik Pemilihan Relay Reaktif
}

\author{
MUHAMMAD RAUDHI AZMI, MELINDA MELINDA, \\ NASARUDDIN NASARUDDIN*
}

Magister Teknik Elektro Fakultas Teknik, Universitas Syiah Kuala, Indonesia Email: raudhiazmi@mhs.unsyiah.ac.id, *nasaruddin@unsyiah.ac.id

*corresponding Author

Received 1 November 2019 | Revised 13 November 2019 | Accepted 6 Desember 2019

\begin{abstract}
ABSTRAK
Sistem komunikasi kooperatif device-to-device (D2D) merupakan salah satu strategi peningkatan kecepatan data dan efisiensi energi. Pada sistem kooperatif, mekanisme relay merupakan faktor penting dalam meneruskan informasi. Model jaringan merupakan isu penting untuk meningkatkan kecepatan, kinerja dan efisiensi energi pada sistem. Oleh sebab itu, makalah ini menganalisis kinerja jaringan hybrid kooperatif D2D pada teknologi 5G menggunakan teknik pemilihan relay reaktif atau reactive relay selection (RRS). Beberapa parameter kinerja penting telah simulasikan, seperti model jaringan, SNR, BER dan throughput. Hasil simulasi menunjukkan bahwa jaringan kooperatif hybrid-relay dengan RRS menghasilkan nilai BER yang lebih kecil dan throughput yang lebih tinggi dibandingkan model multi-relay dan multi-hop relay. Dengan demikian, jaringan hybrid-relay dengan pemilihan relay lebih efisien dibandingkan jaringan lainnya.
\end{abstract}

Kata kunci: sistem komunikasi kooperatif, pemilihan relay reaktif, multi-hop, multi-relay, hybrid-relay.

\begin{abstract}
A device-to-device (D2D) cooperative communication system is one of the strategies to increase data speed and energy efficiency. In a cooperative system, the relay mechanism is an important factor in forwarding information. A network model is an important issue to increase the speed, performance and energy efficiency of the system. Therefore, this paper analyzes the performance of D2D cooperative hybrid networks on $5 G$ technology using reactive relay selection (RRS) techniques. Some important performance parameters have been simulated, such as network models, SNR, BER and throughput. Simulation results show that hybridrelay cooperative networks with RRS produce smaller BER values and higher throughput compared to multi-relay and multi-hop relay models. Thus, hybridrelay networks with relay selection are more efficient than other networks.
\end{abstract}

Keywords: cooperative communication system, reactive relay selection, multihop, multi-relay, hybrid-relay. 


\section{PENDAhuluan}

Sistem komunikasi kooperatif merupakan mekanisme kerjasama antar user yang terdistribusi untuk meningkatkan kinerja sistem dan efisiensi spektrum ( $\mathbf{L i}, \mathbf{H u}, \mathbf{Q i a n}, \boldsymbol{\&} \mathbf{W u}, \mathbf{2 0 1 2}$ ). Pada sistem komunikasi kooperatif, source $(\mathrm{S})$ mengirimkan informasi secara broadcast langsung ke penerima (D) dan ke beberapa relay (R) yang merupakan user lain dalam area yang berada didekatnya. Dalam proses transmisi, jalur pengiriman informasi baik langsung maupun melalui relay saling independen satu sama lain. Komunikasi kooperatif memungkinkan pemanfaatan sumber daya komunikasi yang lebih efisien, karena pada sistem komunikasi kooperatif penggunaan base station (BS) dapat di kurangi.

Sistem komunikasi selular di Indonesia saat ini berada pada era $4 \mathrm{G}$ Long Term Evolution Advanced (LTE-A) yang akan berkembang menuju era $5 G$ (Gupta, 2016). Teknologi $4 G$ diluncurkan pada 2010 oleh Telia Sonera dari Finlandia. Hal ini memberikan solusi yang lebih baik daripada 2G dan 3G. Third Generation Project Partnership (3GPP) telah distandarisasi sebagai LTE-A (Ganesh R. Patil. \& Prashant S.Wankhade, 2014). LTE-A merupakan perkembangan dari generasi LTE dan merupakan teknologi komunikasi yang bergerak pada mobile system yang menjadi dasar sistem 4G. Untuk mempertahankan atau menjaga kualitas jaringan agar tetap bekerja sesuai standarisasi kinerja, maka sebuah jaringan membutuhkan banyak BS. Pengaruh dari penambahan ini mengakibatkan konsumsi energi yang besar dan adanya pemborosan energi. Oleh karena itu, Device-to-Device (D2D) diperkenalkan untuk mengurangi jumlah dari base station (Lien, Chen, \& Lin, 2011).

D2D adalah sebuah sistem komunikasi antara dua perangkat selular yang berdekatan secara langsung tanpa harus melalui BS, penggunaan D2D dapat meningkatkan data rate disebabkan jarak yang lebih dekat (Lien et al., 2011). Komunikasi D2D adalah salah satu pilihan untuk efisiensi pada sistem komunikasi 5G (Gupta, 2016). Kekurangan dari sistem D2D ketika adanya pengguna dari D2D dengan jumlah yang banyak (multi-hop D2D) akan menyebabkan kinerja jaringan akan terbagi dan dapat menurunkan kualitas jaringan, jadi dibutuhkan sebuah model D2D yang dapat menjaga kualitas dari suatu jaringan. Konsep dasar dari sistem komunikasi kooperatif adalah kerja sama antar user yang terdistribusi untuk meningkatkan seluruh kinerja jaringan (Li et al., 2012). Dengan menerapkan sistem komunikasi kooperatif pada sistem D2D dapat mengurangi masalah yang terjadi ketika adanya penumpukan pengguna pada suatu tempat (Cao, Jiang, \& Wang, 2015). Kendala jarak D2D dalam praktiknya memungkinkan jaringan selular mengontrol kondisi saluran rata-rata antara pengguna D2D (Gupta, 2016). Pemilihan relay (relay-selection) merupakan isu penting dalam sistem komunikasi kooperatif nirkabel (Cao et al., 2015). Teknik pemilihan relaydapat meningkatkan kinerja pada sistem dan juga menurunkan konsumsi energi. Makalah lain mengkaji strategi pemilihan relay reactive relay-selection (RRS), dengan mengirimkan informasi pada semua node relay yang tersedia dan relay dengan SNR terbaik yang akan meneruskan informasi ke tujuan pada saat proses pengiriman informasi dari sumber ke tujuan (direct) dinyatakan gagal (Mustafa, Imran, Shakir, Imran, \& Tafazolli, 2016).

Berdasarkan kajian tersebut, penerapan teknik relay-selection dengan protokol kooperatif pada jaringan multi-relay dengan protokol QF (Quantize and forward) belum optimal dari sisi kinerja jaringan, karena penggunaan relay yang selalu sama ketika jarak antar sumber dan tujuan dekat dan jauh (Akhyar, Nasaruddin, \& Muharar, 2017). Selanjutnya, teknik relayselection dengan protokol kooperatif DF (Decode and Forward) pada model jaringan multirelay belum efektif karena tingkat kompleksitas pada protokol DF (Ikki \& Ahmed, 2010). Hingga saat ini, teknik relay selection belum pernah dikaji model jaringan hybrid-relay. 
Jaringan hybrid-relay dengan metode relay selection memiliki keunggulan pada penggunaan relay yang berbeda ketika jarak antar sumber ke tujuan dekat dan jauh.

Makalah ini menganalisis peningkatkan kinerja jaringan yang digunakan pada sistem komunikasi D2D dengan teknik pemilihan relay menggunakan model jaringan hybrid-relay dengan teknik reactive relay selection untuk memperoleh kinerja maksimum dengan protokol amplify and forward (AF). Untuk meningkatkan kinerja jaringan tersebut mempertimbangkan jumlah pengguna D2D yang berubah setiap waktu, dari yang sedang bergerak hingga terjadinya penumpukan pengguna pada suatu tempat. Dengan menerapkan proses pemilihan relay untuk menentukan relayterbaik yang akan digunakan. Makalah ini menggunakan teknik pemilihan relay reaktif, dinamakan reactive relay selection (RRS), untuk menentukan relay terbaik yang akan digunakan, dengan sinyal informasi yang dikirimkan secara broadcast oleh sumber kepada perangkat relay terdekat dan informasi tersebut akan dikuatkan terlebih dahulu sebelum diteruskan ke tujuan. Dengan demikian, penelitan ini dapat berkontribusi dalam meningkatkan kinerja jaringan pada sistem komunikasi nirkabel dengan teknologi 5G yang menjadi isu hangat saat ini.

\section{MODEL SISTEM}

\subsection{Topologi Jaringan}

Model jaringan kooperatif hybrid-relay dengan teknik pemilihan relay yang diusulkan pada makalah ini yang dapat dilihat pada Gambar 1. Model jaringan ini dirancang sesuai dengan kondisi lingkungan yang memungkinkan terdapat banyak device yang berkumpul pada suatu tempat. Model jaringan hybrid merupakan gabungan dari dua model jaringan komunikasi D2D yaitu multi-relay dan multi-hop. Komponen jaringan terdiri dari beberapa node, yaitu: sumber $(S)$, relay $\left(R_{1}, \ldots, R_{k}\right)$, dan tujuan $(D)$.

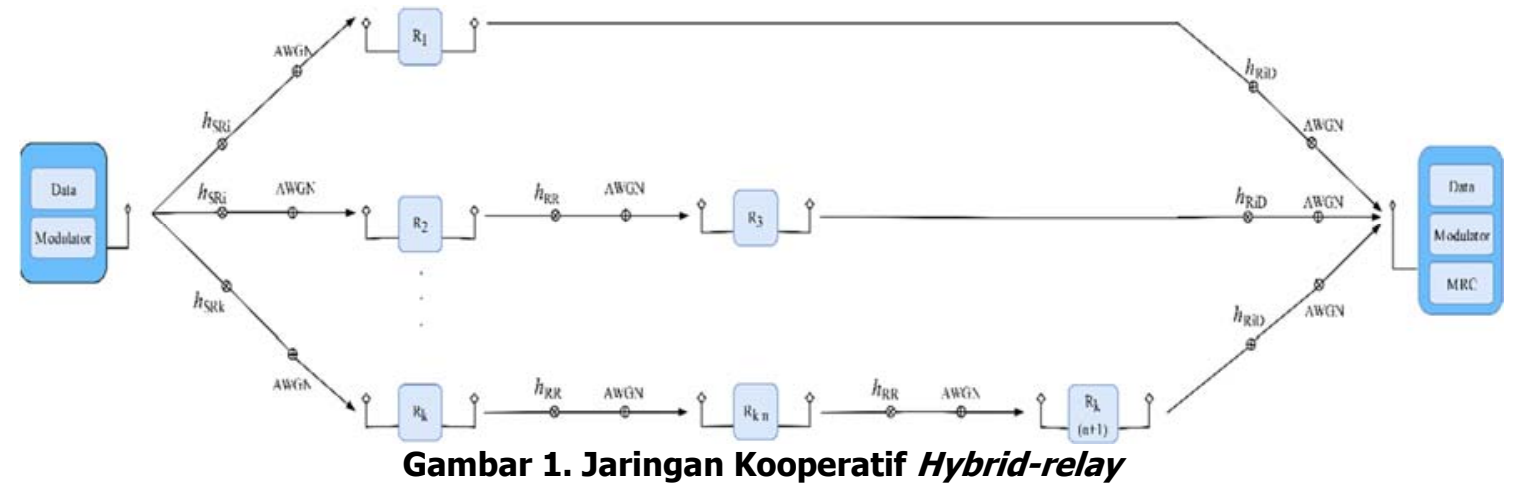

Pada proses jaringan kooperatif hybrid relay sinyal informasi dikirim secara broadcast, sinyal yang dikirim secara broadcast dari sumber akan diterima oleh relay. Pada relay informasi yang diterima akan dikirimkan menuju relay berikutnya dan juga bisa langsung mengirimkan ke tujuan dengan $y_{S, D}$ merupakan sinyal informasi yang dikirimkan dari sumber ke tujuan, $h_{S, D}$ merupakan koefisien fading dari sumber ke tujuan, $x_{s}$ adalah informasi yang dikirimkan dan $n_{S, D}$ merupakan noise AWGN dari sumber ke tujuan dan dituliskan dengan persamaan berikut:

$$
y_{S, D}=h_{S, D} x_{S}+n_{S, D}
$$

Pengiriman sinyal informasi dari node atau perangkat sumber ke tujuan baik secara langsung dan melalui perangkat relay. Proses kerja sistem kooperatif hybrid relay pada makalah ini 
dibagi menjadi beberapa fase atau tahap. Tahap pertama sumber mengirimkan sinyal informasi secara broadcast dalam bentuk data bit yang dinotasikan dengan $\left(x_{S}\right)$ kepada relay ke $i\left(S, R_{i}\right)$ dengan $i=1,2, \ldots, k$, kepada relay berikutnya $(R i, R)$ dan $(R i, D)$ merupakan pengiriman dari relay ke tujuan. Informasi yang diterima pada tujuan dan relay dipengaruhi oleh koefisien fading $(h)$ dan penambahan $(n)$ (Adaptive White Gaussian Noise) AWGN. Pada tahap kedua, relay akan mengirimkan bit informasi menuju relay lain yang berada didekatnya $\left(y_{R, R}\right)$ dan juga bisa mengirimkan langsung ke tujuan $\left(y_{R, D}\right)$. Berdasarkan penelitian A.Ali dan Arshad (Ali, Shah, \& Arshad, 2016) persamaan matematis dapat ditulis sebagai berikut:

$$
\begin{aligned}
& y_{S, R i}=h_{S, R i} x_{S}+n_{S, R} \\
& y_{R, R}=h_{R i, R} x_{r}+n_{R i, R} \\
& y_{R, D}=h_{R i, D} x_{r}+n_{R i, D}
\end{aligned}
$$

\subsection{Metode Pemilihan Relay}

Pada makalah ini menggunakan metode pemilihan relay: reactive relay selection (RRS). Metode RRS merupakan salah satu sistem pemilihan relay yang dilakukan ketika informasi yang dikirimkan langsung ke tujuan mengalami kegagalan. Mekanismenya dapat dilihat pada Gambar 2.

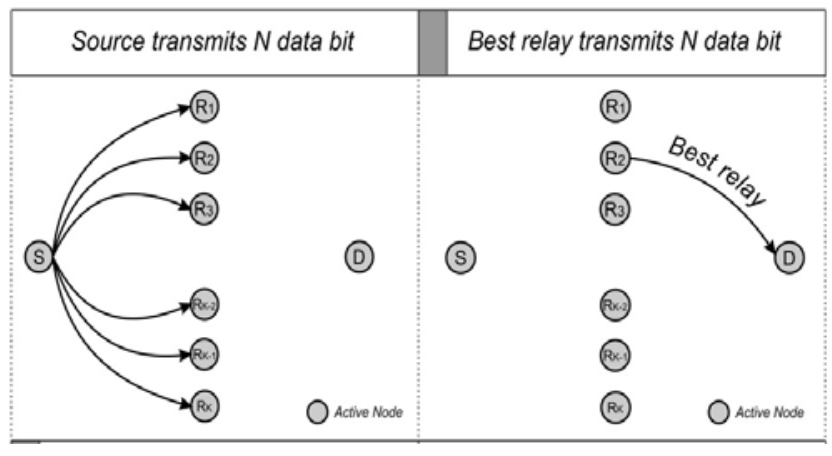

Gambar 2. Strategi Pemilihan Relay

Langkah-langkah yang dilakukan dalam proses pemilihan relay dengan metode RRS sebagai berikut:

1) Tahap pertama sumber mengirimkan informasi secara broadcast berupa bit data (keseluruhan data) kepada beberapa relay yang berada didekatnya. Sinyal informasi yang dikirimkan secara broadcast, selanjutnya sinyal informasi yang dikirimkan dari sumber ke relay dinotasikan dengan $\left(y_{S, R i}\right)$, dengan $h_{S, R i}$ merupakan koefisien fading dari sumber ke relay $i$ dan $n_{S, R i}$ merupakan noise AWGN dari sumber ke relay $i,(i: 1, \ldots, \mathrm{k})$. Sehingga dapat dirumuskan sebagai berikut (Akhyar et al., 2017):

$$
y_{S, R i}=h_{S, R i}+n_{S, R i} ; \text { dengan } i=1, \ldots, n
$$

2) Pada tahap kedua semua relay yang menerima broadcast informasi tersebut akan dipilih. Pemilihan relay terbaik atau best relay $(b)$ dilakukan menggunakan metode CSI (Channel State Information). Metode ini akan memilih relay terbaik berdasarkan nilai SNR terbaiknya, 
perhitungan SNR untuk memilih node relay terbaik yang dapat dirumuskan sebagai berikut (Akhyar et al., 2017):

$$
b=\arg \max \left\{\mathrm{SNR}_{R i, d}\right\} ; b=\text { best relay } i=1, \ldots, k
$$

3) Tahap ketiga sumber akan melakukan request informasi kepada best relay (b).

4) Langkah terakhir adalah best relay meneruskan informasi kepada relay lain yang berada lebih dekat ke tujuan $\left(y_{R, R}\right)$ dan juga dapat mengirimkan langsung ke tujuan $\left(y_{R, D}\right)$ dan $\beta_{i}$ merukan koefisien penguat dari relay $I, \quad y_{R, R}$ adalah sinyal informasi yang diterima di lainnya, $h_{R i, R}$ merupakan koefisien fading dari relay ke relay dan $n_{R i, R}$ merupakan noise AWGN dari relay ke relay, $y_{R, D}$ adalah sinyal informasi yang diterima di tujuan, $h_{R i, d}$ merupakan koefisien fading dari relay ke tujuan dan $n_{R i, d}$ merupakan noise AWGN dari relay ke tujuan. Dapat dirumuskan sebagai berikut (Akhyar et al., 2017):

$$
\begin{aligned}
& y_{R, R}=\left(\beta_{i} h_{R i, R} x_{s}+n_{R i, R}\right) \\
& y_{R, D}=\left(\beta_{i} h_{R i, d} x_{s}+n_{R i, d}\right)
\end{aligned}
$$

Sebelum informasi dari relay diteruskan informasi tersebut akan dikuatkan terlebih dahulu, dengan $P_{i}$ merupakan daya yang digunakan pada relay $i, P_{0}$ adalah daya yang digunakan untuk mengirimkan informasi pada sumber dan $N_{0}$ adalah pengaruh noise saluran dan secara matematis dapat dituliskan sebagai berikut (Nasaruddin, Melinda, \& Elizar, 2014):

$$
\beta_{i}=\sqrt{\frac{P_{i}}{\left(P_{0}\left|h_{s, r i}\right|^{2} N_{0}\right)}}
$$

\subsection{Modulasi Quadrature Amplitude Modulation (M-QAM)}

M-QAM merupakan salah satu teknik modulasi digital multy level yang saat ini banyak digunakan pada sistem komunikasi. QAM merupakan salah satu modulasi digital yang dapat menumpangkan sinyal informasi berupa data biner ke sinyal pembawa berupa sinyal sinusoidal. Modulasi QAM memanfaatkan perubahan fasa dan amplitudo sinyal pembawa dengan saling berbeda fasa sebesar 90 derajat atau dapat dikatakan modulasi QAM adalah modulasi yang merupakan gabungan dari modulasi ASK dan PSK. QAM menggunakan dua pembawa kuadratur yaitu cos $2 \pi f c t$ dan sin 2nfct masing-masing dimodulasikan oleh beberapa bit informasi (Mohamad, Mahmud, \& Awang, 2011). Pada makalah ini menggunakan beberapa modulasi QAM. Bentuk-bentuk modulasi yang digunakan adalah 8-QAM, 16-QAM, 32-QAM, dan 64-QAM.

\section{SKEMA PENGUJIAN}

\subsection{Parameter Simulasi}

Simulasi yang dilakukan didalam makalah ini menggunakan beberapa parameter, diantaranya adalah jumlah bit data yang dikirimkan adalah 100000 bit. Pengiriman dengan jumlah bityang besar dilakukan dengan pertimbangan pertukaran informasi yang besar pada sistem komunikasi. Hal yang penting juga menjadi parameter dalam simulasi adalah jumlah node relay lebih dari satu dan juga data rate pada parameter mempengaruhi hasil throughput. Parameter lainnya adalah penggunaan jangkauan SNR 0-20 dB yang menjadi acuan dalam 
transmisi informasi. Keterangan lengkap dari parameter yang digunakan dalam simulasi dapat dilihat pada Tabel 1.

Tabel 1. Parameter Simulasi

\begin{tabular}{|l|l|l|}
\hline No & \multicolumn{1}{|c|}{ Parameter } & \multicolumn{1}{c|}{ Keterangan } \\
\hline 1 & Jumlah Bit Data & 100.000 bit \\
\hline 2 & Model kanal & Rayleigh fading \\
\hline 3 & Jumlah sumber & 1 \\
\hline 4 & Jumlah relay & 6 \\
\hline 5 & Jumlah tujuan & 1 \\
\hline 6 & Teknik Modulasi & m-QAM $(\mathrm{m}=16,32$ dan 64$)$ \\
\hline 7 & Protokol relay & AF \\
\hline 8 & Jarak sumber - relay - tujuan & Tetap dan Bergerak \\
\hline 9 & Rasio Jarak & $0.1-0.9$ \\
\hline 10 & Data Rate & $1 \mathrm{Gbps}$ \\
\hline 11 & SNR $(\mathrm{dB})$ & $0-20 \mathrm{~dB}$ \\
\hline
\end{tabular}

\subsection{Kinerja Jaringan}

Berdasarkan model topologi dan strategi pemilihan relay, kinerja jaringan pada jaringan komunikasi kooperatif nirkabel hybrid-relay AF merupakan faktor penting yang perlu dianalisis pada artikel ini. Ada beberapa faktor yang perlu dihitung untuk mengukur tingkat kinerja jaringan.

1) $B E R$ adalah pengukuran kinerja yang menentukan Jumlah bit rusak atau hancur sebagaimana adanya ditransmisikan dari sumbernya ke tujuannya (Nasaruddin et al., 2014). Beberapa faktor-faktor yang mempengaruhi BER termasuk bandwidth, signal-tonoise ratio (SNR), kecepatan transmisi dan transmisi medium. Dengan $x_{s}$ adalah informasi yang dikirimkan dan jumlah error adalah kesalahan yang terjadi ketika pengiriman yang dilakukan dari sumber ke tujuan dengan $y_{R i, D}$ merupakan informasi yang diterima pada tujuan. Definisi laju kesalahan bit dapat diterjemahkan menjadi formula sederhana (Sadinov, 2017):

$$
\begin{aligned}
& B E R=\frac{\text { jumlah error }}{x_{S}} \\
& \text { Jumlah error }=y_{R i, D}-x_{S}
\end{aligned}
$$

2) Throughput adalah banyaknya ukuran data informasi yang dapat dilewatkam dan diterima dari source menuju destination untuk setiap satuan waktu atau dapat diartikan banyaknya paket data yang berhasil dikirimkan ke penerima dari sejumlah usaha pengiriman informasi setiap detik. Persamaan throughput dapat dirumuskan sebagai berikut, dengan $E(r)$ adalah throughput (Gbps) dan $r$ adalah bit rate (Gbps) (Ikki \& Ahmed, 2010).

$$
E(r)=(1-B E R) r
$$

BER adalah kemungkinan terjadinya outage yaitu kemungkinan terjadinya kegagalan pengiriman informasi yang dapat ditentukan dengan menggunakan persamaan (Marchenko \& Bettstetter, 2011). 


\section{HASIL DAN ANALISIS}

Proses simulasi pengiriman informasi dari sumber ke tujuan dilakukan dengan metode sistem komunikasi kooperatif reactive relay-selection (RRS) dan model-model jaringan kooperatif D2D. Kemudian, makalah ini membandingkan nilai BER dan throughput berdasarkan perubahan nilai SNR dan rasio jarak. Hasil pada makalah ini sebagai berikut:

\subsection{Bit Error Rate}

Proses simulasi BER berdasarkan jarak dengan membandingkan antara tiga model jaringan, yaitu model multi-relay, multi-hop relay dan model hybrd-relay. Untuk BER yang dihasilkan dari ketiga model jaringan tersebut nilai hybrid-relay menjadi model dengan nilai BER terbaik diantara kedua model lain yaitu multi-hop relay dan multi-relay. Dari kedua hasil simulasi BER berdasarkan rasio jarak pada proses pemilihan relay dengan metode reactive relay-selection (RRS) dihasilkan 4,61 $\times 10^{-5}$ bit untuk model hybrid-relay, 5,15 $\times 10^{-5}$ bit pada model multihop relay dan $5,49 \times 10^{-5}$ bit pada model multi-relay, seperti ditunjukkan pada Gambar 3 .

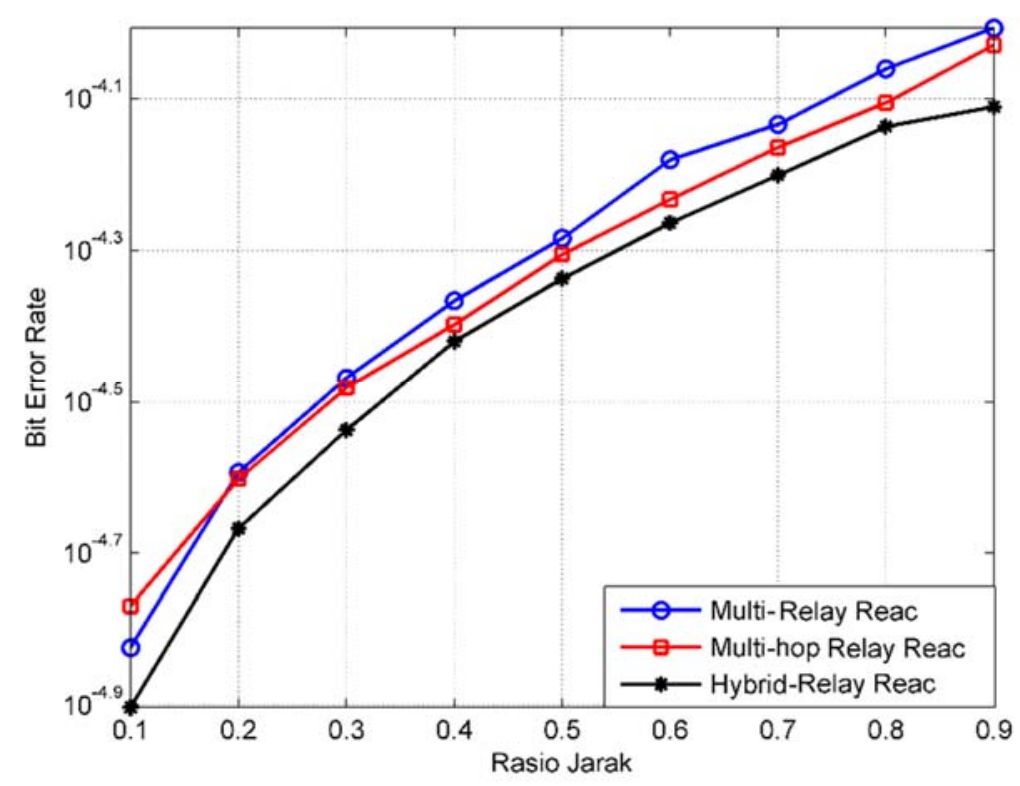

Gambar 3. BER Terhadap Jarak Pada Tiga Model Jaringan

Berdasarkan hasil simulasi ini menunjukkan bahwa tingkat kesalahan transmisi pada jaringan hybrid lebih kecil dibandingkan dengan kedua model jaringan lainnya yaitu multi-relay dan multi-hop relay. Dengan kata lain, jaringan hybrid memberi banyak pilihan bagi sumber untuk memilih relay yang terbaik dengan SNR yang kuat, sehingga tingkat kesuksesan dalam mentransmisikan informasi ke tujuan semakin tinggi. 


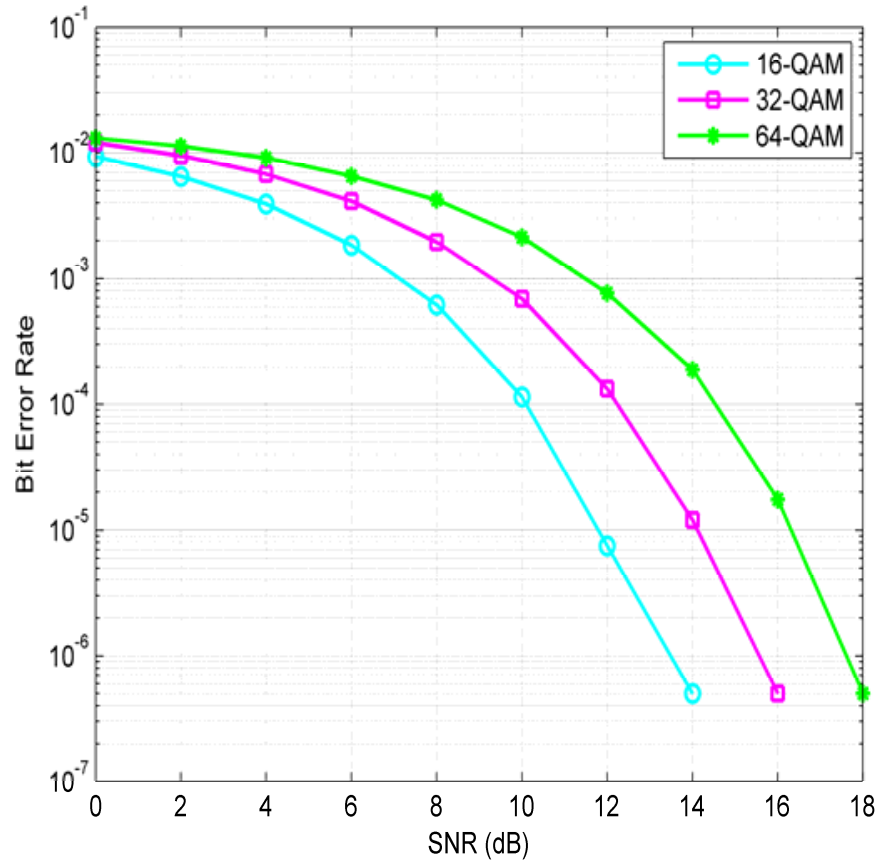

Gambar 4. BER Terhadap SNR Pada Tiga Tipe Modulasi Untuk Jaringan hybrid-relay

Makalah ini juga mensimulasi beberapa tipe modulasi QAM pada jaringan hybrid D2D yang merupakan modulasi yang akan digunakan pada teknologi $5 \mathrm{G}$. Hasil simulasi BER berdasarkan SNR membandingkan antara tiga model modulasi, yaitu 16-QAM, 32-QAM dan 64-QAM, seperti pada Gambar 4. Pada simulasi, jarak relay dalam jaringan diasumsikan pada posisi tetap atau perangkat relay dengan jarak tertentu. Hasil simulasi BER menggunakan metode RRS untuk modulasi 16-QAM adalah 0,002019 bit, kemudian dibandingkan dengan modulasi 32-QAM sebesar 0,003211 bit dan dengan 64-QAM menghasilkan 0,004309 bit. Hasil simulasi menunjukkan bahwa semakin tinggi orde dari QAM yang digunakan, maka tingkat kesalahan informasi waktu transmisi akan semakin besar. Secara teori, hal ini adalah valid karena semakin banyak bit dalam suatu symbo/maka peluang kegagalan (kesalahan) akan semakin tinggi.

\subsection{Throughput}

Simulasi throughput dilakukan untuk ketiga model jaringan. Parameter perbandingannya adalah variasi jarak relay dan variasi nilai SNR. Disamping itu, throughput jaringan juga disimulasikan dengan tipe modulasi QAM yang berbeda.

Hasil simulasi throughput berdasarkan jarak dengan metode pemilihan relay RRS dapat dilihat pada Gambar 5. Secara umum, throughput yang dihasilkan pada jaringan hybrid lebih tinggi dibandingkan dua model jaringan lainnya. 


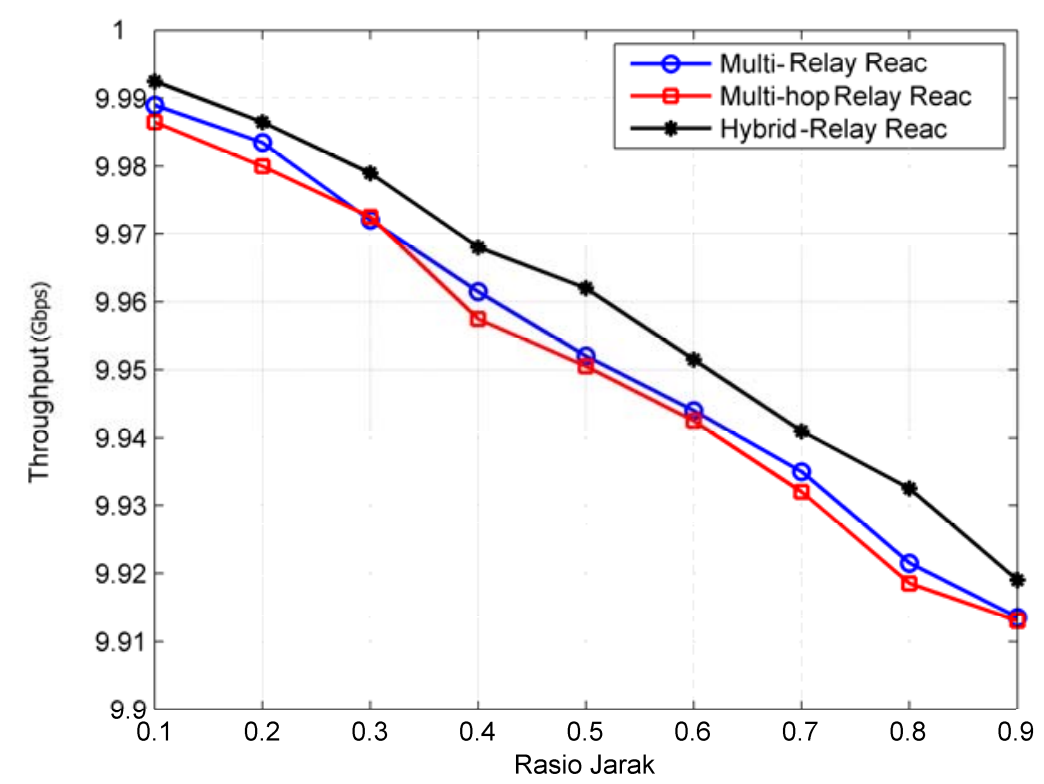

Gambar 5. Throughput Terhadap Jarak Pada Tiga Model Jaringan

Pada hasil throughput untuk jaringan multi-relay adalah sebesar 0,999944 Gbps, 0,999948 Gbps pada multi-hop relay, dan 0,999953 Gbps pada hybrid-relay. Kemudian, throughputakan semakin kecil ketika jarak relay bertambah dan tingkat kuat sinyal akan berkurang dan kegagalan transmisi bit juga bertambah, maka throughput yang dihasilkan akan menurun.

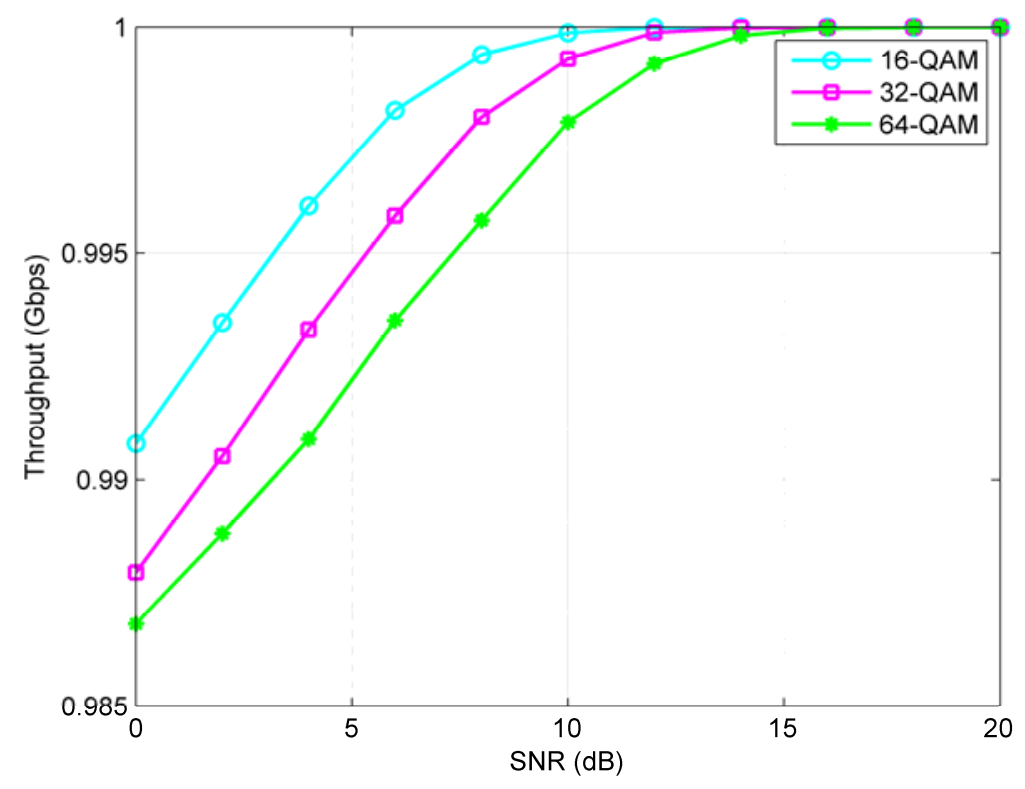

\section{Gambar 6. Throughput Terhadap SNR Pada Tiga Modulasi Untuk Jaringan Hybrid-relay}

Pada Gambar 6 menunjukkan hasil simulasi throughput berdasarkan SNR untuk tiga tipe modulasi QAM yaitu 16-QAM, 32-QAM dan 64-QAM pada jaringan hybrid-relay menggunakan metode pemilihan relay RRS. Pada simulasi, throughput yang dihasilkan sebesar 0,997983 Gbps untuk modulasi 16-QAM, 0,996793 Gbps pada modulasi 32-QAM dan 0,995694 Gbps 
pada modulasi 64-QAM. Hal ini sinkron dengan hasil BER untuk masing-masing tipe modulasi, dengan orde modulasi rendah menghasilkan throughput yang lebih tinggi dibandingkan dengan order modulasi yang lebih tinggi karena tingkat BER pada modulasi orde tinggi lebih besar dibandingkan dengan modulasi orde rendah. Dengan demikian, jaringan hybrid-relay D2D dengan modulasi orde rendah QAM lebih cocok digunakan pada teknologi $5 \mathrm{G}$ untuk menghasilkan throughput maksimal terutama pada saat jarak relay dengan sumber relatif pendek.

\section{KESIMPULAN}

Penelitian ini telah menganalisis kinerja jaringan pada sistem komunikasi kooperatif hybridrelay AF menggunakan teknik pemilihan relay RRS yang digunakan untuk komunikasi kooperatif device to device (D2D) untuk teknologi 5G. Model jaringan hybrid-relay telah dikaji dengan beberapa parameter yang mempengaruhi kinerja. Simulasi komputer telah dilakukan untuk mendapatkan kinerja BER dan throughput untuk jaringan multi-relay, multi-hop relay dan usulan makalah jaringan hybrid-relay. Selanjutnya penelitian ini juga membandingkan beberapa modulasi signal, yaitu: 16-QAM, 32-QAM dan 64-QAM. Hasil simulasi model hybridrelay $\mathrm{AF}$ dengan strategi pemilihan relay RRS menunjukkan bahwa kinerja BERnya lebih rendah dibandingkan dengan jaringan multi-relay dan multi-hop relay. Kinerja modulasi QAM pada jaringan hybrid-relay menunjukkan bahwa orde modulasi yang rendah menghasilkan kinerja BER yang baik dan tingkat kesalahan transmisi semakin kecil dibandingkan dengan modulasi orde tinggi. Selanjutnya, kinerja throughput juga telah disimulasikan, throughput jaringan hybrid-relay menghasilkan throughput yang lebih tinggi dibandingkan dengan dua jaringan lainnya. Hasil simulasi berdasarkan tipe modulasi juga telah dilakukan yang menunjukkan 16QAM menghasilkan throughput yang lebih tinggi dibandingkan dengan dua tipe modulasi lainnya. Dengan demikian, jaringan hybrid-relay lebih sesuai untuk diimplementasikan pada komunikasi D2D teknologi 5G dengan kinerja yang tinggi. Untuk memaksimalkan throughput jaringan, modulasi QAM orde rendah (16-QAM) lebih tepat untuk diterapkan pada kooperatif D2D teknologi 5G.

\section{UCAPAN TERIMAKASIH}

Makalah ini merupakan salah satu bagian dari penelitian dasar yang dibiayai oleh Kemenristekdikti Tahun 2019 No. 51/UN11.2/PP/SP3/2019.

\section{DAFTAR RUJUKAN}

Akhyar, F., Nasaruddin, N., \& Muharar, R. (2017). Efisiensi Energi Sistem Komunikasi Kooperatif Multi-relay Quantize and Forward Berdasarkan Pemilihan Relay. Jurnal Nasional Teknik Elektro Dan Teknologi Informasi (JNTETI), 6(1), 66-73.

Ali, A., Shah, G. A., \& Arshad, J. (2016). Energy efficient techniques for M2M communication: A survey. Journal of Network and Computer Applications, 68, 42-55.

Cao, Y., Jiang, T., \& Wang, C. (2015). Cooperative device-to-device communications in cellular networks. IEEE Wireless Communications, 22(3), 124-129.

Ganesh R. Patil., \& Prashant S.Wankhade. (2014). 5G Wireless Technology. International Journal of Trend in Scientific Research and Development, 3(10), 203-207. 
Gupta, A. B. M. (2016). A Survey on Wireless Technology 5G. International Journal of Innovative Research in Computer and Communication Engineering, 4(9), 1633016337.

Ikki, S. S., \& Ahmed, M. H. (2010). Performance analysis of adaptive decode-and-forward cooperative diversity networks with best-relay selection. IEEE Transactions on Communications, 58(1), 22-29.

Li, Q., Hu, R. Q., Qian, Y., \& Wu, G. (2012). Cooperative communications for wireless networks: Techniques and applications in LTE-advanced systems. IEEE Wireless Communications, 19(2), 16330-16337.

Lien, S. Y., Chen, K. C., \& Lin, Y. (2011). Toward ubiquitous massive accesses in 3GPP machine-to-machine communications. IEEE Communications Magazine, 49(4), 66-74.

Marchenko, N., \& Bettstetter, C. (2011). Throughput and energy efficiency of cooperative diversity with relay selection. 17th European Wireless Conference 2011, (pp. 1-6).

Mohamad, R., Mahmud, R., \& Awang, R. A. (2011). Prototype of Quadrature Amplitude Modulation (QAM) baseband modem for a digital baseband signal processor. 2011 IEEE International RF and Microwave Conference, RFM 2011 - Proceedings, (pp. 407- 411).

Mustafa, H. A. U., Imran, M. A., Shakir, M. Z., Imran, A., \& Tafazolli, R. (2016). Separation framework: An enabler for cooperative and D2D communication for future 5G networks. IEEE Communications Surveys and Tutorials, 18(1), 419-445.

Nasaruddin, N., Melinda, M., \& Elizar, E. (2014). Optimized Power Allocation for Cooperative Amplify-and-Forward with Convolutional Codes. TELKOMNIKA Indonesian Journal of Electrical Engineering, 12(8), 6243-6253.

Sadinov, S. M. (2017). Simulation study of M-ARY QAM modulation techniques using Matlab/Simulink. 2017 40th International Convention on Information and Communication Technology, Electronics and Microelectronics, MIPRO 2017 Proceedings, (pp. 547-554). 